\title{
A Uterine Myoma Affecting Hemodynamics: A Case Report
}

\author{
Hemodinamiyi Etkileyen Uterin Miyom: Olgu Sunumu
}

\section{Serdar ÖZDEMIR (1)}

Department of Emergency Medicine, Health Sciences University Umraniye Training and Research Hospital, Istanbul, Turkey

ORCID ID: Serdar Özdemir 0000-0002-6186-6110

Cite this article as: Özdemir S. A Uterine Myoma Affecting Hemodynamics: A Case Report. Med J West Black Sea. 2021;5(2):287-289.

Corresponding Author

Serdar Özdemir

E-mail

dr.serdar55@hotmail.com

Received

14.10.2020

Revision

06.02.2021

Accepted

19.02.2021

\begin{abstract}
Uterine myomas are one of the most common causes of abnormal uterine bleeding. A 44-year-old female patient presented to the emergency service with weakness and palpitation that had started on the previous day. She had been experiencing vaginal bleeding for ten days. On her physical examination, the vital signs of the patient were recorded as follows: pulse, 121 beats/min (rhythmic); and blood pressure, $90 / 49 \mathrm{mmHg}$. The other system examinations were within normal limits. According to the laboratory test, hemoglobin was $6.7 \mathrm{~g} / \mathrm{dl}$ and hematocrit was 21.5 . On the ultrasonographic examination, a 158x136 $\mathrm{mm}$ mass consistent with a myoma was observed. The patient's vaginal bleeding continued during her hospitalization. Hysterectomy and bilateral salpingectomy were performed. The patient was discharged on post-operative day two without any complications. Uterine myomas, especially submucosal large myomas affect hemodynamics by causing abnormal uterine bleeding.
\end{abstract}

Keywords: Abnormal uterine bleeding, Hemodynamics, Uterine myomas, Case report

öz

Uterin miyomlar, anormal uterin kanamanın en yaygın nedenlerinden biridir. 44 yaşında kadın hasta bir gündür devam eden halsizlik ve çarpıntı ile kliniğimize başvurdu. On gündür devam eden vajinal kanama öyküsü mevcuttu. Fizik muayenesinde hastanın vital bulguları şu şekilde kaydedildi; nabız: $121 \mathrm{atım} / \mathrm{dk}$, ritmik, kan basıncı: 90/49 mmHg. Diğer sistem incelemeleri normal sınırlar içindeydi. Laboratuvar sonuçları hemoglobin: $6.7 \mathrm{~g} / \mathrm{dl}$, hematokrit: $21.5 \mathrm{idi}$. Ultrasonografik incelemede, 158x136 $\mathrm{mm}$ boyutlarında miyomlarla uyumlu kitle izlendi. Hastanın hastanede yattığı süre boyunca vajinal kanaması devam etti. Histerektomi ve bilateral salpenjektomi yapıldı. Hasta postoperatif 2. günde herhangi bir komplikasyon olmaksızın taburcu edildi. Uterin miyomlar, özellikle submukozal büyük miyomlar, anormal uterin kanamayla hemodinamiyi etkileyebilirler.

Anahtar Sözcükler: Anormal uterin kanama, Uterin miyoma, Hemodinami, Olgu sunumu 


\section{INTRODUCTION}

Uterine myomas are one of the most common causes of abnormal uterine bleeding and are mostly located under the mucosal layer. Submucous myomas cause anemia with severe menstrual bleeding (1) and are mostly diagnosed at outpatient clinics during a routine gynecological examination. Patients may present to the emergency department with excessive bleeding, irregular bleeding, and intermediate bleeding.

In this case report, we describe a case of myoma uteri, presenting to the emergency department with deep anemia and stage III hemorrhagic shock.

\section{CASE REPORT}

A 44-year-old female patient presented to the emergency department with weakness and palpitation that had started on the previous day. She had also been experiencing vaginal bleeding for ten days. She presented to the emergency department due to epistaxis that occurred twice on the last three days. In the anamnesis of the patient, there were diabetes mellitus and hypertension. There was no history of trauma or anticoagulant use. Her obstetric history showed no complications during or after previous deliveries.

On the physical examination, the vital signs of the patient were recorded as follows: pulse, 121 beats/min (rhythmic); blood pressure, 90/ $49 \mathrm{mmHg}$; respiratory rate, 17 breaths/ min; room air oxygen saturation, $98 \%$; and body temperature, $36.1^{\circ} \mathrm{C}$. The physical examination revealed that her general status was moderate, and she had vaginal bleeding. The examination of the other systems showed normal findings. Electrocardiography was normal except for sinus tachycardia. The laboratory results were hemoglobin $6.7 \mathrm{~g} /$ $\mathrm{dl}$, hematocrit 21.5, mean corpuscular volume $9.8 \mathrm{fL}$, mean corpuscular hemoglobin 15.7 pg., and mean corpuscular hemoglobin concentration $26.2 \mathrm{~g} / \mathrm{dL}$. Biochemical parameters were within normal limits. The ultrasonographic examination revealed a $158 \times 136 \mathrm{~mm}$ mass, consistent with a myoma .

Three units of erythrocyte suspension and one unit of fresh frozen plasma were given intravenously. At the sixth-hour control examination, her vital signs were stable. The patient was admitted to the gynecology clinic for follow-up.

Contrast-enhanced pelvic magnetic resonance imaging showed a $17 \times 13 \mathrm{~cm}$ heterogeneous lesion in the uterus, filling the fundus and corpus and containing heterogeneous gross fibroids showing contrast enhancement (Figure 1). The mass was extending to the supraumbilical region up to the lower pole level of the kidney.

The patient's vaginal bleeding continued during her hospitalization at the gynecology clinic. Seven units of erythrocyte suspension and three units of fresh frozen plasma were given intravenously during hospitalization. Hysterectomy and bilateral salpingectomy were performed. The patient was discharged from the gynecology clinic in good health on the postoperative second day.

The final pathology on uterine fragments revealed the endometrium without atypia, adenomyosis, and submucosal leiomyoma in the uterus. No malignancy was identified in any of the specimens.

\section{DISCUSSION}

Uterine myomas are benign monoclonal tumors originating from the smooth muscles of the myometrium. They are the most common tumors of the female genital system (2). Myomas are often asymptomatic but may cause various symptoms associated with tumor size and localization. The most common symptom is abnormal uterine bleeding (3). They may cause pain symptoms such as chronic pelvic pain, dysmenorrhea, and dyspareunia. However, bladder, rectum and ureteral compression may also lead to the development of polyuria, constipation, tenesmus, hydroureter, and hydronephrosis (2). Especially the submucous type results in implantation problems and causes infertility. Our case presented with abnormal uterine bleeding and pelvic pain.

The most common non-traumatic cause of blood loss leading to such severe anemia is gastrointestinal hemorrhage. There are some cases in the literature with severe anemia caused by uterine myomas. Algın et al. reported the lowest hemoglobin level ever in a patient without a noisy clinical table (4). Their patient was admitted to the outpatient clinic with normal vital signs. Our patient was unstable and had stage III shock.

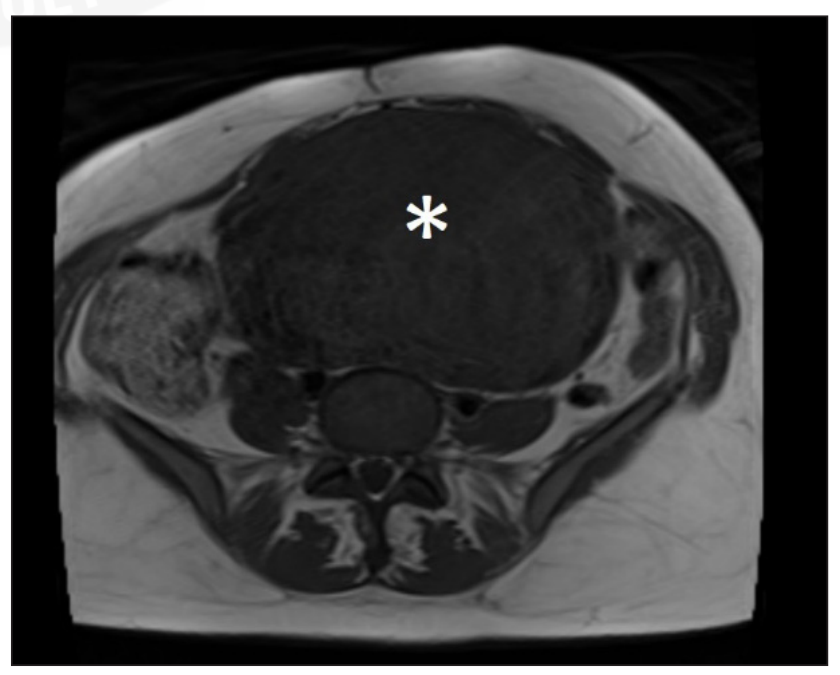

Figure 1: Contrast-enhanced abdominal MRI showing a 17x13 $\mathrm{cm}$ mass with an exophytic extension, filling the fundus and corpus and containing heterogeneous gross fibroids (asterisk). 
Treatment options for uterine myomas are expectorant, surgical, medical and uterine artery embolization. In the selection of the treatment option, factors such as age, desire for fertility, symptoms, and suspicion of malignancy are evaluated. A conservative approach may be an entirely acceptable treatment approach, particularly in peri-menopausal cases with amenorrhea and when the regression of fibroid size is imminent.

In a retrospective study, Puri et al. showed that submucosal myomas diagnosed hysteroscopically were associated with a low hemoglobin level and anemia (5). Lasmar and Lasmar showed that the submucous type of myomas was more often related to abnormal uterine bleeding (6). Wegienka et al. reported that leiomyomas were associated with a higher risk of heavy bleeding, and this risk was further increased with the increasing size of the myoma (7). Our patient had a large submucosal leiomyoma, and she presented with stage III hemorrhagic shock.

\section{Acknowledgment}

None.

\section{Author Contrubitons}

Serdar Özdemir reviewed the literature and wrote up the paper. Critical revisions made by Serdar Özdemir.

\section{Conflicts of Interest}

We declare no conflict of interest.

\section{Financial Support}

We received no financial support for the research, authorship, or publication of this article.

\section{Ethical Approval}

Since it was a case report, ethics committee approval was not required. We asked the patient to help us to publish the case report in an international journal for discussion, including disease symptoms, diagnosis, and image related content. She agreed us to use her medical records and signed the consent form. Legal permission has been obtained.

Peer Review Process

Extremely peer-reviewed.

\section{REFERENCES}

1. Kısa Karakaya B, Kansu Çelik H. Keçecioğlu M, Evliyaoğlu Ö, Sarıkaya E, Erkaya S. Submuköz myom boyutu ve serum hemoglobin seviyesi arasındaki ilişki. Jinekoloji - Obstetrik ve Neonatoloji Tıp Dergisi 2017;14(2):45-47.

2. Yavuz A, Astepe B, Terzi H, Kale A. Dev uterin myomda yönetim: Olgu sunumu. Sakarya Tıp Dergisi 2015; 5(1): 38-34.

3. Fraser IS, Critchley HO, Munro MG, Broder M; Writing Group for this Menstrual Agreement Process. A process designed to lead to international agreement on terminologies and definitions used to describe abnormalities of menstrual bleeding. Fertil Steril 2007;87:466.

4. Algin A, Tayfur I, Afacan M, Çolak Ş, Sarıaydın M, Findikli $H$, Aydın $\mathrm{H}$. Life-threatening anemia diagnosis due to myoma uteri in the emergency department: A case report. Journal of Emergency Medicine Case Reports 2019; 10(1): 25-24.

5. Puri K, Famuyide AO, Erwin PJ, Stewart EA, Laughlin-Tommaso SK. Submucosal fibroids and the relation to heavy menstrual bleeding and anemia. Am J Obstet Gynecol 2014;210(38):1-7.

6. Lasmar RB, Lasmar BP. The role of leiomyomas in the genesis of abnormal uterine bleeding (AUB). Best Pract Res Clin Obstet Gynaecol 2017;40:82-88.

7. Wegienka G, Baird DD, Hertz-Picciotto I, Harlow SD, Steege JF, Hill MC, Schectman JM, Hartmann KE. Self-reported heavy bleeding associated with uterine leiomyomata. Obstet Gynecol 2003;101 (3): 431-437. 